\title{
Enzymatic activity of Lactobacillus reuteri grown in a sweet potato based medium with the addition of metal ions
}

\author{
Saeed A Hayek ${ }^{* \dagger}$, Aboghasem Shahbazi, Mulumebet Worku and Salam A Ibrahim ${ }^{\dagger}$
}

\begin{abstract}
The effect of metal ions on the enzymatic activity of Lactobacillus reuteri was studied. The enzymatic activity was determined spectrophotometrically using the corresponding substrate. In the control group, L. reuteri MF14-C, MM2-3, SD2112, and DSM20016 produced the highest a-glucosidase (40.06 $\pm 2.80 \mathrm{Glu} \mathrm{U/mL),} \beta$-glucosidase $(17.82 \pm 1.45 \mathrm{Glu} \mathrm{U} / \mathrm{mL})$, acid phosphatase $(20.55 \pm 0.74 \mathrm{Ph} \mathrm{U} / \mathrm{mL})$, and phytase $(0.90 \pm 0.05 \mathrm{Ph} \mathrm{U} / \mathrm{mL})$ respectively. The addition of $\mathrm{Mg}^{2+}$ and $\mathrm{Mn}^{2+}$ led to enhance $a$-glucosidase produced by $\mathrm{L}$. reuteri MM2-3 by $113.6 \%$ and $100.6 \%$ respectively. $a$-Glucosidase produced by MF14-C and CF2-7F was decrease in the presence of $\mathrm{K}^{+}$by 65.8 and $69.4 \%$ respectively. $\beta$-Glucosidase activity of MM7 and SD2112 increased in the presence of $\mathrm{Ca}^{2+}$ (by 121.8 and $129.8 \%$ ) and $\mathrm{Fe}^{2+}$ (by 143.9 and 126.7\%) respectively. Acid phosphatase produced by L. reuteri CF2-7F and MM2-3 was enhanced in the presence of $\mathrm{Mg}^{2+}, \mathrm{Ca}^{2+}$ or $\mathrm{Mn}^{2+}$ by $(94.7,43.2$, and $70.1 \%)$ and $(63.1,67.8$, and $45.6 \%)$ respectively. On the other hand, $\mathrm{Fe}^{2+}, \mathrm{K}^{+}$, and $\mathrm{Na}^{+}$caused only slight increase or decrease in acid phosphatase activity. Phytase produced by $L$. reuteri MM2-3 was increase in the presence of $\mathrm{Mg}^{2+}$ and $\mathrm{Mn}^{2+}$ by 51.0 and $74.5 \%$ respectively. $\mathrm{Ca}^{2+}$ enhanced phytase activity of MM2-3 and DSM20016 by 27.5 and $28.9 \%$ respectively. The addition of $\mathrm{Na}^{+}$or Fe ${ }^{2+}$ decreased phytase activity of $\mathrm{L}$. reuteri. On average, $\mathrm{Mg}^{2+}$ and $\mathrm{Mn}^{2+}$ followed by $\mathrm{Ca}^{2+}$ led to the highest enhancement of the tested enzymes. However, the effect of each metal ion on the enzymatic activity of $L$. reuteri was found to be a strain dependent. Therefore, a maximized level of a target enzyme could be achieved by selecting a combination of specific strain and specific metal ion.
\end{abstract}

Keywords: L. reuteri; Metal ions; $\mathrm{Mg}^{2+} ; \mathrm{Mn}^{2+}$; a-glucosidase; $\beta$-glucosidases; Acid phosphatase; Phytase

\section{Introduction}

Species of the genus lactobacilli are commonly found in a diversity of ecosystems including human, animal, plants, and soil (Barrangou et al. 2011; Song et al. 2012). Lactobacillus has been employed in many applications with regard to food, feed, and fertilizers. This genus of lactic acid bacteria is the lead of food fermentation and probiotic applications (Rodríguez et al. 2009; Song et al. 2012). Lactobacillus produces several functional enzymes that could help in the digestibility of complex carbohydrates such as indigestible fibers and benefit the human health (Mahajan et al. 2010; Palacios et al.

\footnotetext{
* Correspondence: safesaeed@yahoo.com

${ }^{\dagger}$ Equal contributors

Food Microbiology and Biotechnology Laboratory, 163 Carver Hall, Greensboro, North Carolina Agricultural and Technical State University, Greensboro, NC 27411, USA
}

2007; Raghavendra and Halami 2009; Zotta et al. 2007). For example, $\alpha$-glucosidase ( $\alpha$-D-glucoside glucohydrolase, EC 3.2.1.20) is responsible for hydrolyzing glycosidic bonds in oligosaccharides (starch, disaccharides, and glycogen) and releasing $\alpha$-glucose (Krasikov et al. 2001). Deficiency of $\alpha$-glucosidase in human could cause glycogen storage disease II which also known as Pompe (Krasikov et al. 2001). $\beta$-Glucosidase ( $\beta$-D-glucoside glucohydrolase, EC 3.2.1.21) hydrolyzes all four $\beta$-linked glucose dimmers in cellulose to produce glucose monomers (Sestelo et al. 2004). Cellulose is considered the highest proportion of plants, and can be hydrolyzed by $\beta$-glucosidases for both industry and human health. Humans are unable to digest cellulose due to the low levels of cellulases in the gut. $\beta$-Glucosidase is also used in the production of fuel ethanol from cellulose and in food fermentation to release the aromatic compounds 
(Sestelo et al. 2004). Acid phosphatase (orthophosphoric monoester phosphohydrolase, EC. 3.1.3.2) and phytase (myo-inositol hexakisphosphate 6-phosphohydrolases; EC 3.1.3.26) hydrolyze phytate and reduce its antinutritional properties (Iqbal et al. 1994; López-González et al. 2008; Palacios et al. 2005). The specificity of acid phosphatase and phytase can partially overlapped since acid phosphatase produced by microorganisms has phytase activity (Simon and Igbasan 2002). Phytate is a common fiber that found in cereals, legumes, and nuts, and acts as an antinutrient binding with proteins, lipids, carbohydrates, and metal ions (zinc, iron, calcium, and magnesium). Phytate degrading activity in humans is relatively low (mainly in the small intestine) (Iqbal et al. 1994), so other sources of phytate degrading enzymes are required. Microbial sources of such functional enzymes could be the most promising sources for human health.

Utilization of indigestible fibers and oligosaccharides, not digestible by human enzymes, has been recognized as an important attribute of probiotics (Alazzeh et al. 2009; Gyawali and Ibrahim 2012; Song et al. 2012). Species of Lactobacillus that produce functional enzymes such as $\alpha$-glucosidase, $\beta$-glucosidase, acid phosphatase, and phytase could have an important impact on human health. However, the production capacity of such hydrolyzing enzymes by Lactobacillus is strain specific (Bury et al. 2001; Ibrahim et al. 2010; Palacios et al. 2007; Zotta et al. 2009; Zotta et al. 2007). Lactobacillus reuteri is known to inhabit the gastrointestinal tract of humans and animals (Casas and Dobrogosz 2000). L. reuteri is a special probiotic species since the entire species has been shown to exhibit efficient probiotic functionality (Casas and Dobrogosz 2000) and to produce different functional enzymes (Alazzeh et al. 2009). L. reuteri exhibit high activity of $\alpha$-galactosidase and $\beta$-galactosidase (Ibrahim et al. 2010). Strains of L. reuteri have high activity of $\alpha$-glucosidase (Kralj et al. 2005) and $\beta$-glucosidase (Otieno et al. 2005). These strains also showed the highest phytate degrading activity producing both phytase and acid phosphatase compare to other Lactobacillus spp. (Palacios et al. 2007). We have previously shown that $L$. reuteri produce higher $\alpha$-glucosidase, acid phosphatase, and phytase than other Lactobacillus spp. (Hayek 2013).

In addition to human health applications, these probiotic strains can be also used in animals and plants. However, the enzymatic activity of Lactobacillus can be affected by their nutritional requirements such as vitamins metal ions, sugars, and protein (Alazzeh et al. 2009; Hayek and Ibrahim 2013; Ibrahim et al. 2010; Mahajan et al. 2010; Palacios et al. 2005). Nevertheless, even though the nutritional requirements of Lactobacillus have been established, controlling, optimizing, and maximizing the enzymatic activity of Lactobacillus have many limitations and challenges (Hayek and Ibrahim 2013). Metal ions have been reported in several studies to enhance the enzymatic activity of Lactobacillus spp. including L. reuteri (Aqel 2012; Ibrahim et al. 2010; Ozimek et al. 2005; Palacios et al. 2005). For example, the addition of $10 \mathrm{mM}$ of $\mathrm{Mn}^{2+}$ caused a significant enhancement in $\beta$ glucosidase activity while $10 \mathrm{mM}$ of $\mathrm{Zn}^{2+}$ or $\mathrm{Cu}^{2+}$ resulted in a reduction of $\beta$-glucosidase of up to $90 \%$. (Jeng et al. 2011). Acid phosphatase was enhanced by $\mathrm{Ca}^{2+}$ and $\mathrm{Mg}^{2+}$ with a greater effect on $\mathrm{Ca}^{2+}$ (Tham et al. 2010). Thus, developing a means to enhance the enzymatic activity of $L$. reuteri may help to solve different digestive problems.

Sweet potatoes (Ipomoea batatas (L.) Lam.) (Batatas an Arawak name) are an abundant agricultural product that play a major role in the food industry and human nutrition. Sweet potatoes are a rich source of carbohydrates (mainly starch and sugars), some amino acids, vitamins (vitamin A, vitamin $\mathrm{C}$, thiamin (B1), riboflavin (B2), niacin, and vitamin E), minerals (calcium, iron, magnesium, phosphorus, potassium, sodium, and zinc), and dietary fiber (Broihier 2006; Padmaja 2009). Sweet potatoes also contain other minor nutrients such as antioxidants, triglycerides, linoleic acid, and palmitic acid (Broihier 2006; Padmaja 2009). Previous studies have shown that plant components can support the growth and functionality of probiotic bacteria (Gyawali and Ibrahim 2012). We have previously showed that sweet potatoes could be used to form an alternative low cost medium for the growth of Lactobacillus strains (Hayek et al. 2013). Lactobacillus strains grown in a sweet potato base medium were also found to produce higher $\beta$-glucosidase, acid phosphatase, and phytase activities and lower $\alpha$-glucosidase than that in MRS (Hayek 2013). However, the suitability of the sweet potato base medium to study the effect of metal ions on the enzymatic activity of $L$. reuteri was not investigated. Therefore, the objective of this work was to study the effect of metal ions on $\alpha$-glucosidase, $\beta$-glucosidase, acid phosphatase, and phytase activity of $L$. reuteri growing in a sweet potato based medium.

\section{Materials and methods}

\section{Media preparation}

Sweet potato medium (SPM) was previously developed to support the growth of Lactobacillus (Hayek et al. 2013). Fresh sweet potatoes (Covington cultivar) (obtained from Burch Farms in Faison NC, USA) were baked in a conventional oven at $400^{\circ} \mathrm{C}$ for $1 \mathrm{~h}$. The sweet potatoes were then peeled and blended in a kitchen blender with deionized distilled water (DDW) at a ratio of 1:2. The solution was centrifuged at $7800 \times \mathrm{g}$ for $10 \mathrm{~min}$ using Sorvall RC 6 Plus Centrifuge (Thermo Scientific Co., Asheville, NC, USA) and the supernatant was collected. SPM was then formed by mixing $1 \mathrm{~L}$ of supernatant with the following ingredients: sodium acetate $(5 \mathrm{~g})$, potassium 
monophosphate (2 g), disodium phosphate ( $2 \mathrm{~g})$, ammonium citrate $(2 \mathrm{~g})$, Tween $80(1 \mathrm{~mL})$, beef extract (Neogen Corporation, Lansing, MI, USA) (4 g), yeast extract (Neogen Corporation) (4 g), proteose peptone \#3 (4 g), and L-Cysteine $(1 \mathrm{~g})$. SPM was sterilized at $121^{\circ} \mathrm{C}$ for 15 min, cooled down, and stored at $4^{\circ} \mathrm{C}$ then used within 3 days. All ingredients were obtained from Thermo Scientific Co. (Asheville, NC, USA) unless otherwise noted.

\section{Bacterial culture activation and preparation}

L. reuteri strains (Table 1 ) were provided by BioGaia (Raleigh, NC) and stored in the stock collection of the Food Microbiology and Biotechnology Laboratory, North Carolina A\&T State University. The strains were activated in SPM by transferring $100 \mu \mathrm{L}$ of stock culture to $10 \mathrm{~mL}$ SPM broth, incubated at $37^{\circ} \mathrm{C}$ for $24 \mathrm{~h}$, and stored at $4^{\circ} \mathrm{C}$. Prior to each experimental replication, bacterial strains were streaked on SPM agar and incubated for $48 \mathrm{~h}$ at $37^{\circ} \mathrm{C}$. One isolated colony was then transferred to $10 \mathrm{~mL}$ SPM broth and incubated at $37^{\circ} \mathrm{C}$ for next day use.

\section{Culturing with metal ions}

Samples of SPM with metal ions were prepared by dissolving $10 \mathrm{mM}$ of either $\mathrm{FeSO}_{4} .4 \mathrm{H}_{2} \mathrm{O}, \mathrm{MgSO}_{4} .7 \mathrm{H}_{2} \mathrm{O}$, $\mathrm{K}_{2} \mathrm{SO}_{4}$, or $\mathrm{Na}_{2} \mathrm{SO}_{4}$, or $5 \mathrm{mM}$ of either $\mathrm{MnSO}_{4}{ }_{4} \mathrm{H}_{2} \mathrm{O}$ or $\mathrm{CaSO}_{4} .7 \mathrm{H}_{2} \mathrm{O}$ into batches of $60 \mathrm{~mL}$ non-sterile preprepared SPM. The use of $10 \mathrm{mM}$ or less of metal ions was established to avoid the hypertonic pressure on bacterial cells (Ibrahim et al. 2010). The used $5 \mathrm{mM}$ of $\mathrm{MnSO} 4.4 \mathrm{H}_{2} \mathrm{O}$ and $\mathrm{CaSO}_{4} .7 \mathrm{H}_{2} \mathrm{O}$ was required since higher concentrations did not dissolve completely in SPM. Batches of $60 \mathrm{~mL}$ SPM without metal ions served as control. Samples were sterilized at $121^{\circ} \mathrm{C}$ for $15 \mathrm{~min}$, cooled down to room temperature, then inoculated with $3 \% \mathrm{v} / \mathrm{v}$ precultured $L$. reuteri and incubated at $37^{\circ} \mathrm{C}$ for $16 \mathrm{~h}$. Bacterial growth was monitored by measuring the turbidity (optical density (OD) at $610 \mathrm{~nm}$ ) at $2 \mathrm{~h}$ intervals using a 96-well microplate reader (BioTek Institute, Winooski, VT). At the end of incubation, cultures were divided into two portions of $30 \mathrm{~mL}$ each. One portion was used for $\alpha$-glucosidase and $\beta$-glucosidase determination and the other portion was used for acid phosphatase and phytase determination.

Table 1 Lactobacillus reuteri strains and sources

\begin{tabular}{cc}
\hline L. reuteri & Source \\
\hline MF14-C & Mother fecal isolate \\
CF2-7F & Child fecal isolate \\
DSM20016 & Mother's milk \\
SD2112 & Mother's milk \\
MM7 & Mother's milk \\
MM2-3 & Mother's milk \\
\hline
\end{tabular}

\section{Enzyme samples preparation}

Samples used for $\alpha$-glucosidase and $\beta$-glucosidase determination were centrifuged at $7800 \times \mathrm{g}$ for $10 \mathrm{~min}$ at $4^{\circ} \mathrm{C}$ using Sorvall RC 6 Plus Centrifuge to harvest the bacterial cells. The cells were washed twice with $0.5 \mathrm{M}$ sodium phosphate buffer ( $\mathrm{pH}$ 6.0) and suspended in $1 \mathrm{~mL}$ of the same buffer. Suspended cells were maintained in Eppendorf tubes containing $0.1 \mathrm{~mm}$ glass beads and treated with a mini-Beadbeater-8 (Biospec Products, Bartlesville, OK, USA) for a total of $3 \mathrm{~min}$ to disrupt the cells. During cells disruption, samples were allowed to rest after each minute for $15 \mathrm{~s}$ in an ice bath to avoid overheating. Samples were then centrifuged at 12,000 $\times$ g for $20 \mathrm{~min}$ using Microcentrifuge $5415 \mathrm{R}$ (Eppendorf, Hamburg, Germany) and supernatant was used for enzyme assay analysis of $\alpha$-glucosidase. Disrupted cells were suspended in a minimum amount of sodium phosphate buffer and used for enzyme assay analysis of $\beta$-glucosidase.

Samples used for acid phosphates and phytase determination were centrifuged at $7800 \times$ g for $10 \mathrm{~min}$ at $4^{\circ} \mathrm{C}$ to harvest the bacterial cells. The cells were washed with $50 \mathrm{mM}$ Tris- $\mathrm{HCl}(\mathrm{pH}$ 6.5) and suspended in $1 \mathrm{~mL}$ $50 \mathrm{mM}$ sodium acetate-acetic acid $(\mathrm{pH}$ 5.5). Suspended cells were disrupted then centrifuged using same procedure as that of samples used for $\alpha$-glucosidase and $\beta$ glucosidase. Supernatants were used for enzyme assay analysis of acid phosphatase and phytase.

\section{Determination of $\alpha$-glucosidase and $\beta$-glucosidase}

$\alpha$-Glucosidase and $\beta$-glucosidase were determined by monitoring the rate of hydrolysis of $\rho$-nitrophenyl- $\alpha$-Dglucopyranoside ( $\alpha$-PNPG) and $\rho$-nitrophenyl- $\beta$-D-glucopyranoside $(\beta$-PNPG) respectively according to Mahajan and others with some modifications (Mahajan et al. 2010). In this procedure $1 \mathrm{~mL}$ of $10 \mathrm{mM}$ of either ( $\alpha$-PNPG) or $(\beta$-PNPG) was mixed with $0.5 \mathrm{~mL}$ of the corresponding enzyme sample. Samples were then incubated at $37^{\circ} \mathrm{C}$ for $20 \mathrm{~min}$. All reactions were stopped by adding $2.5 \mathrm{~mL}$ of $0.5 \mathrm{M} \mathrm{Na}_{2} \mathrm{CO}_{3}$. The released yellow $\rho$-nitrophenol was determined by measuring the OD at $420 \mathrm{~nm}$. One unit of $\alpha$-glucosidase or $\beta$-glucosidase (Glu $\mathrm{U} / \mathrm{mL}$ ) was defined as $1.0 \mu \mathrm{M}$ of $\rho$-nitrophenol liberated per minute under assay conditions.

\section{Determination of acid phosphatase and phytase}

Acid phosphatase (E.C.3.1.3.2.) was determined by monitoring the rate of hydrolysis of $\rho$-nitrophenyl phosphate (PNPP), and phytase activity was determined by measuring the amount of liberated inorganic phosphate from sodium phytate (Haros et al. 2008). For acid phosphatase, $250 \mu \mathrm{L}$ of $0.1 \mathrm{M}$ sodium acetate buffer $(\mathrm{pH} 5.5)$ containing $5 \mathrm{mM}$ PNPP was mixed with $250 \mu \mathrm{L}$ of enzyme sample. Samples were then incubated at $50^{\circ} \mathrm{C}$ for 
$30 \mathrm{~min}$ in a water bath, the reaction was stopped by adding $0.5 \mathrm{~mL}$ of $1.0 \mathrm{M} \mathrm{NaOH}$ and the released $\rho$ nitrophenol was measured at $420 \mathrm{~nm}$. For phytase, $400 \mu \mathrm{L}$ of $0.1 \mathrm{M}$ sodium acetate $(\mathrm{pH}$ 5.5) containing $1.2 \mathrm{mM}$ sodium phytate was mixed with $250 \mu \mathrm{L}$ of enzyme sample. Samples were then incubated for $30 \mathrm{~min}$ at $50^{\circ} \mathrm{C}$ in a water bath, the reaction was stopped by adding $100 \mu \mathrm{L}$ of $20 \%$ trichloroacetic acid solution. An aliquot was analyzed to determine the liberated inorganic phosphate $(\mathrm{Pi})$ by the ammonium molybdate method, OD at $420 \mathrm{~nm}$ (Tanner and Barnett 1986). One unit of acid phosphatase or phytase $(\mathrm{Ph} \mathrm{U} / \mathrm{mL})$ was defined as $1.0 \mu \mathrm{M}$ of $\rho$-nitrophenol or $1.0 \mu \mathrm{M}$ of Pi liberated per minute under assay conditions.

\section{Statistical analysis}

Each experimental test was conducted three times in randomized block design to evaluate the effect of metal ions on the enzymatic activity of $L$. reuteri in SPM. Mean values and standard deviations were calculated from the triplicate tested samples. R Project for Statistical Computing version R-2.15.2 (www.r-project.org) was used to determine significance of differences in the effect of metal ions on the enzymatic activity of the tested L. reuteri strains and significance of differences in the enzymatic activity among strains using one way and multiway ANOVA (analysis of variance) with a significance level of $p<0.05$.

\section{Results and discussions}

Effect of metal ions on the growth of Lactobacillus reuteri The growth of $L$. reuteri was monitored using OD at 610 nm. Figure 1 shows average growth rates of $L$. reuteri strains growing in SPM with added metal ions during $16 \mathrm{~h}$ of incubation at $37^{\circ} \mathrm{C}$. In the control samples, strains of $L$. reuteri continued to grow and reached an average of $1.75 \mathrm{OD}(610 \mathrm{~nm})$ within $16 \mathrm{~h}$ of incubation at $37^{\circ} \mathrm{C}$. The addition of $\mathrm{Mg}^{2+}$ or $\mathrm{Mn}^{2+}$ to SPM enhanced the growth of $L$. reuteri to reach an average of 1.94 and $1.90 \mathrm{OD}(610 \mathrm{~nm})$ respectively. $\mathrm{Fe}^{2+}$ and $\mathrm{Ca}^{2+}$ slows down the growth of $L$. reuteri to reach an average of 1.63 and 1.57 OD $(610 \mathrm{~nm})$ respectively. Similar growth curves were shown for the strains of $L$. reuteri in the presence of $\mathrm{Na}^{+}$and $\mathrm{K}^{+}$as control group. All tested strains of $L$. reuteri grew better in SPM with added $\mathrm{Mn}^{2+}$ or $\mathrm{Mg}^{2+}$, and they grew slower in SPM with added $\mathrm{Fe}^{2+}$ and $\mathrm{Ca}^{2+}$ compared to their in control (Figure 2). The addition of $\mathrm{Na}^{+}$to SPM enhanced the growth of MF14-C, CF2-7F, and DSM20016 but slowed down the growth of SD2112, MM7, and MM2-3. $\mathrm{K}^{+}$ showed only slight effect on the growth of the tested strains.

The enhancement $L$. reuteri growth by $\mathrm{Mn}^{2+}$ and $\mathrm{Mg}^{2+}$ can be explained by that these metal ions are essential for the growth of Lactobacillus (Boyaval 1989; Letort and Juillard 2001; Wegkamp et al. 2010). $\mathrm{Mn}^{2+}$ helps the cell to deal with reactive oxygen species and serves as an alternative for the absence of a gene encoding a superoxide dismutase (Wegkamp et al. 2010). $\mathrm{Mg}^{2+}$ was earlier found to stimulates the growth of Lactobacillus and improve its survival (Amouzou et al. 1985). It was shown that $\mathrm{Mg}^{2+}$ is the only essential oligoelement for the growth of Lactobacillus delbrueckii subsp. lactis (Hébert et al. 2004). $\mathrm{Mg}^{2+}$ and $\mathrm{Mn}^{2+}$ were found to be essential minerals for the growth of L. plantarum (Wegkamp et al. 2010). In this experiment we are reporting the enhancement of $L$. reuteri growth by $\mathrm{Mn}^{2+}$ and $\mathrm{Mg}^{2+}$.

\section{Induction of $a$-glucosidase by metal ions}

In control group, $\alpha$-glucosidase activity produced by $L$. reuteri ranged between $20.65 \pm 1.70$ and $40.06 \pm 2.80$ Glu U/mL for MM2-3 and MF14-C respectively (Table 2).

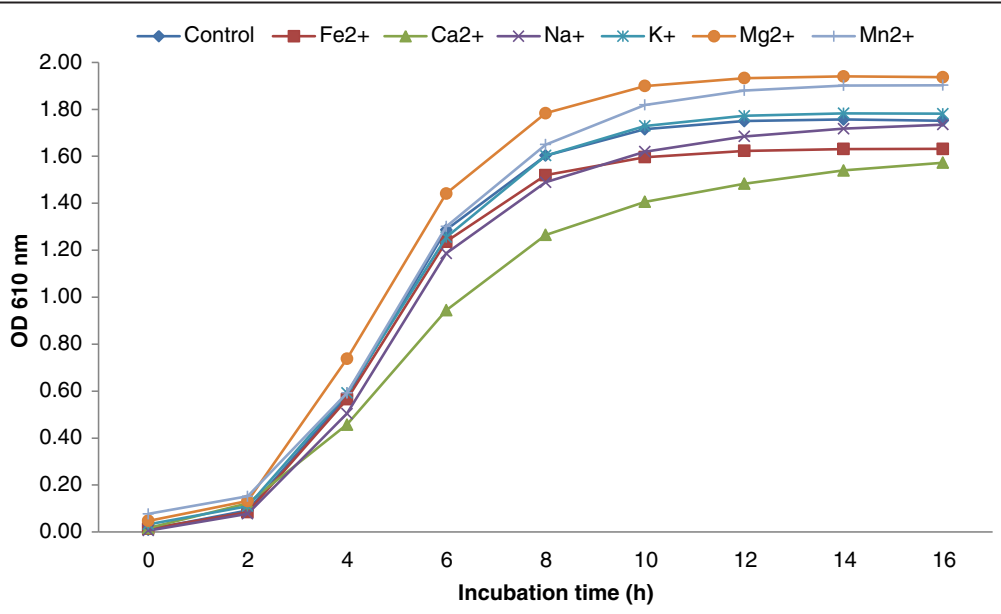

Figure 1 Effect of adding metal ions on the growth pattern of $L$. reuteri (results of six strains of $L$. reuteri were pooled for each metal ion). 


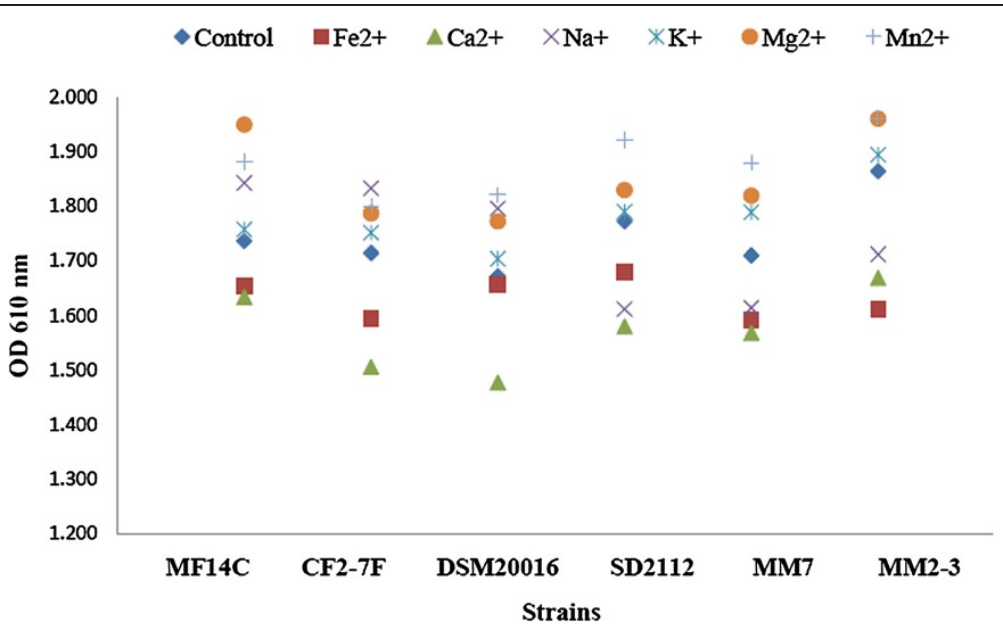

Figure 2 Effect of adding metal ions on the growth of $L$. reuteri strains after $16 \mathrm{~h}$ of incubation.

In the presence of $\mathrm{Mg}^{2+}, \alpha$-glucosidase produced by $L$. reuteri MM2-3 was increased by 23.46 units to reach $44.11 \pm 3.20 \mathrm{Glu} \mathrm{U} / \mathrm{mL}$. L. reuteri MF14-C grown in the presence of $\mathrm{Mg}^{2+}$ showed the highest $\alpha$-glucosidase activity $(61.74 \pm 3.09 \mathrm{Glu} \mathrm{U} / \mathrm{mL})$ compared to other strains. The addition of $\mathrm{Mn}^{2+}$ also enhanced $\alpha$-glucosidase activity L. reuteri MM2-3 and MF14-C to reach $41.42 \pm 3.66$ and $58.31 \pm 2.88$ respectively. $\mathrm{Mn}^{2+}$ enhanced $\alpha$-glucosidase activity for all $L$. reuteri strains except CF2-7F. On the other hand, the addition of $\mathrm{K}^{+}$reduced $\alpha$-glucosidase of MF14-C to reach $13.71 \pm 1.70 \mathrm{Glu} \mathrm{U} / \mathrm{mL}$. The growth of L. reuteri in the presence of $\mathrm{K}^{+}$led to a significant $(p<$ $0.05)$ decrease in $\alpha$-glucosidase activity in all strains. The addition of $\mathrm{Fe}^{2+}$ also reduced $\alpha$-glucosidase of MF14-C, $25.90 \pm 2.72$ Glu U/mL. Fe ${ }^{2+}$ decreased $\alpha$-glucosidase activity of all $L$. reuteri strains except
DSM20016 and MM2-3. $\mathrm{Ca}^{2+}$ enhanced $\alpha$-glucosidase activity of DSM20016, MM7, and MM2-3 and decreased the activity of MF14-C, CF2-7F, and SD2112. $\mathrm{Na}^{+}$enhanced $\alpha$-glucosidase activity for all $L$. reuteri strains except MF14-C which was not affected.

Figure 3 shows the relative activity (\%) of $\alpha$-glucosidase produced by $L$. reuteri in the presence of metal ions. $\alpha$ Glucosidase activity of MM2-3 growing in SPM with the addition of $\mathrm{Mg}^{2+}$ and $\mathrm{Mn}^{2+}$ was increase by $113.6 \%$ and $100.6 \%$ respectively. $\mathrm{Mg}^{2+}$ and $\mathrm{Mn}^{2+}$ also increased $\alpha$-glucosidase activity of DSM20016 (by 59.2 and 74.6\%) and MF14-C (by 54.1 and $45.6 \%$ ) respectively. $\mathrm{Mg}^{2+}$ and $\mathrm{Mn}^{2+}$ were also found earlier to stimulate $\alpha$-glucosidase activity of L. acidophilus ( $\mathrm{Li}$ and Chan 1983). The addition of $\mathrm{Na}^{+}$also enhanced $\alpha$-glucosidase activity of the tested L. reuteri strains while showing less effect than $\mathrm{Mg}^{2+}$ and

Table 2 Effect of metal ions on $a$-glucosidase activity (Glu U/mL) produced by L. reuteri

\begin{tabular}{|c|c|c|c|c|c|c|c|}
\hline \multirow[b]{2}{*}{ L. reuteri } & \multicolumn{7}{|c|}{$a$-Glucosidase activity (Glu $\mathrm{U} / \mathrm{mL})^{*}$} \\
\hline & Control & $\mathrm{Fe}^{2+}$ & $\mathrm{Ca}^{2+}$ & $\mathrm{Na}^{+}$ & $\mathrm{K}^{+}$ & $\mathrm{Mg}^{2+}$ & $\mathrm{Mn}^{2+}$ \\
\hline \multirow{2}{*}{ MF14-C } & 40.06 & 25.90 & 26.32 & 38.38 & 13.71 & 61.74 & 58.31 \\
\hline & $\pm 2.80^{\mathrm{bA}}$ & $\pm 2.72^{\mathrm{CA}}$ & $\pm 3.50^{\mathrm{CB}}$ & $\pm 1.98^{\mathrm{bB}}$ & $\pm 1.70^{\mathrm{dBC}}$ & $\pm 3.09^{\mathrm{aA}}$ & $\pm 2.88^{\mathrm{aA}}$ \\
\hline \multirow{2}{*}{ CF2-7F } & 34.38 & 20.48 & 25.20 & 47.59 & 10.52 & 46.30 & 32.83 \\
\hline & $\pm 1.36^{\mathrm{bB}}$ & $\pm 1.75^{\mathrm{CB}}$ & $\pm 1.83^{\mathrm{CB}}$ & $\pm 1.86^{\mathrm{aA}}$ & $\pm 1.30^{\mathrm{dc}}$ & $\pm 2.64^{\mathrm{aB}}$ & $\pm 2.91^{\mathrm{bc}}$ \\
\hline \multirow{2}{*}{ DSM20016 } & 31.80 & 30.20 & 41.69 & 46.14 & 26.22 & 50.64 & 55.52 \\
\hline & $\pm 2.01^{\mathrm{dBC}}$ & $\pm 2.27^{\mathrm{dA}}$ & $\pm 2.89^{\mathrm{CA}}$ & $\pm 2.66^{\mathrm{bcA}}$ & $\pm 1.09^{\mathrm{dA}}$ & $\pm 1.30^{\mathrm{aB}}$ & $\pm 4.68^{\mathrm{aA}}$ \\
\hline \multirow{2}{*}{ SD2112 } & 29.34 & 19.54 & 20.57 & 34.58 & 15.59 & 35.51 & 40.55 \\
\hline & $\pm 1.27^{\mathrm{CC}}$ & $\pm 3.89 \mathrm{~dB}$ & $\pm 1.82^{\mathrm{dC}}$ & $\pm 2.32^{\mathrm{abB}}$ & $\pm 1.11^{\mathrm{dB}}$ & $\pm 2.74^{\mathrm{abc}}$ & $\pm 1.90^{\mathrm{aB}}$ \\
\hline \multirow{2}{*}{ MM7 } & 25.32 & 19.40 & 35.93 & 37.57 & 12.59 & 28.13 & 35.68 \\
\hline & $\pm 2.32^{\mathrm{cdCD}}$ & $\pm 1.75^{\mathrm{deB}}$ & $\pm 3.62^{\mathrm{abA}}$ & $\pm 4.39^{\mathrm{aB}}$ & $\pm 1.83^{\mathrm{eBC}}$ & $\pm 3.22^{\mathrm{bcD}}$ & $\pm 2.63^{\mathrm{abc}}$ \\
\hline \multirow{2}{*}{ MM2-3 } & 20.65 & 18.28 & 24.79 & 24.98 & 14.79 & 44.11 & 41.42 \\
\hline & $\pm 1.70^{\mathrm{bcE}}$ & $\pm 1.49^{\mathrm{bcB}}$ & $\pm 2.72^{\mathrm{bB}}$ & $\pm 2.30^{\mathrm{bc}}$ & $\pm 2.60^{\mathrm{eB}}$ & $\pm 3.20^{\mathrm{aB}}$ & $\pm 3.66^{\mathrm{aB}}$ \\
\hline
\end{tabular}




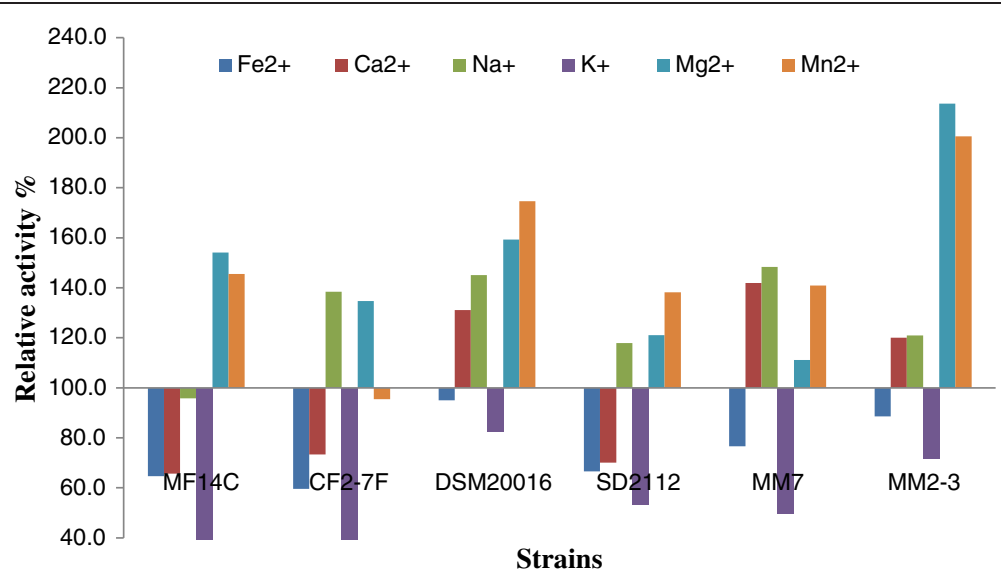

Figure 3 Relative activity (\%) of $a$-glucosidase produced by L. reuteri grown is SPM with added metal ions compared to the control group without metal ions. The relative activity was calculated as the enzymatic activity in SPM with added metal ions divided by the enzymatic activity in SPM without metal ions then multiplied by 100.

$\mathrm{Mn}^{2+}$. On the other hand, the growth of L. reuteri in SPM with added $\mathrm{K}^{+}$led to a decrease in $\alpha$-glucosidase ranged between $17.5-65.8 \%$. Thus the effect of metal ions on $\alpha$-glucosidase activity of $L$. reuteri is strain specific. These results come in agreement with previous studies. For example, $\alpha$-glucosidase produced by $L$. rhamnosus $\mathrm{R}$ was inhibited by $\mathrm{Hg}^{2+}, \mathrm{Mn}^{2+}, \mathrm{Cu}^{2+}, \mathrm{Fe}^{2+}$ and $\mathrm{Zn}^{2+}$ and slightly activated by $\mathrm{Li}^{+}, \mathrm{Na}^{+}, \mathrm{K}^{+}, \mathrm{Ca}^{2+}, \mathrm{Co}^{2+}$, and $\mathrm{Mg}^{2+}$ (Pham et al. 2000). In addition, our results suggest the use of MF14-C and DSM20016 in the presence of $\mathrm{Mg}^{2+}$ and $\mathrm{Mn}^{2+}$ to produce enhanced levels of $\alpha$-glucosidase.

\section{Induction of $\beta$-glucosidase by metal ions}

In control group, $\beta$-glucosidase activity of $L$. reuteri ranged between $6.94 \pm 1.29$ and $17.82 \pm 1.45 \mathrm{Glu} \mathrm{U} / \mathrm{mL}$ for MF14$\mathrm{C}$ and MM2-3 respectively (Table 3). The addition of $\mathrm{K}^{+}$ increased $\beta$-glucosidase produced by $L$. reuteri MF14-C and MM2-3 to reach $13.71 \pm 1.70$ and $24.79 \pm 2.60 \mathrm{Glu} \mathrm{U/}$ $\mathrm{mL}$ respectively. $\mathrm{K}^{+}$also increased $\beta$-glucosidase $L$. reuteri DSM20016 to reach the highest activity among the tested strains, $26.22 \pm 1.09 \mathrm{Glu} \mathrm{U} / \mathrm{mL}$. The addition of $\mathrm{Ca}^{2+}$ or $\mathrm{Fe}^{2+}$ to SPM significantly $(p<0.05)$ enhanced $\beta$-glucosidase activity in all tested strains. $\mathrm{Mg}^{2+}$ and $\mathrm{Mn}^{2+}$ also enhanced $\beta$-glucosidase activity in the tested strains but showed lower enhancement effect compared to $\mathrm{Ca}^{2+}$, $\mathrm{Fe}^{2+}$ or $\mathrm{K}^{+}$. The lowest $\beta$-glucosidase with metal ions was produced by $L$. reuteri MF14-C in the presence of $\mathrm{Ca}^{2+}(9.66 \pm 2.17 \mathrm{Glu} \mathrm{U} / \mathrm{mL})$. Thus, the addition of metal ions to SPM could enhance $\beta$-glucosidase activity of L. reuteri.

The growth of $L$. reuteri in the presence of metal ions led to relative change in $\beta$-glucosidase ranged between -1.7 to

Table 3 Effect of metal ions on $\beta$-glucosidase activity (Glu U/mL) produced by L. reuteri

\begin{tabular}{|c|c|c|c|c|c|c|c|}
\hline \multirow[b]{2}{*}{ L. reuteri } & \multicolumn{7}{|c|}{$\beta$-Glucosidase activity $(\text { Glu } \mathrm{U} / \mathrm{mL})^{*}$} \\
\hline & Control & $\mathrm{Fe}^{2+}$ & $\mathrm{Ca}^{2+}$ & $\mathrm{Na}^{+}$ & $\mathrm{K}^{+}$ & $\mathrm{Mg}^{2+}$ & $\mathrm{Mn}^{2+}$ \\
\hline \multirow{2}{*}{ MF14-C } & 6.94 & 11.46 & 9.66 & 11.18 & 13.71 & 10.15 & 12.30 \\
\hline & $\pm 1.29^{c \mathrm{C}}$ & $\pm 1.66^{\mathrm{abc}}$ & $\pm 2.17^{\mathrm{bC}}$ & $\pm 1.60^{\mathrm{abc}}$ & $\pm 1.70^{\mathrm{aBC}}$ & $\pm 1.74^{\mathrm{bD}}$ & $\pm 1.29^{\mathrm{aB}}$ \\
\hline \multirow{2}{*}{ CF2-7F } & 10.11 & 18.02 & 21.93 & 16.86 & 10.52 & 13.60 & 16.71 \\
\hline & $\pm 1.58^{\mathrm{cB}}$ & $\pm 2.21^{\mathrm{aAB}}$ & $\pm 2.05^{\mathrm{aA}}$ & $\pm 1.12^{\mathrm{abB}}$ & $\pm 1.30^{\mathrm{cD}}$ & $\pm 1.13^{\mathrm{bC}}$ & $\pm 1.93^{\mathrm{abA}}$ \\
\hline \multirow{2}{*}{ DSM20016 } & 12.04 & 21.05 & 22.45 & 18.24 & 26.22 & 20.57 & 16.87 \\
\hline & $\pm 1.05^{\mathrm{dB}}$ & $\pm 2.23^{\mathrm{bA}}$ & $\pm 1.70^{\mathrm{bA}}$ & $\pm 1.75^{\mathrm{bcB}}$ & $\pm 1.09^{\mathrm{aA}}$ & $\pm 1.28^{\mathrm{bAB}}$ & $\pm 1.08^{\mathrm{cdA}}$ \\
\hline \multirow{2}{*}{ SD2112 } & 7.59 & 17.21 & 17.44 & 10.46 & 15.59 & 17.50 & 13.28 \\
\hline & $\pm 1.20^{\mathrm{cdC}}$ & $\pm 1.94^{\mathrm{aAB}}$ & $\pm 1.90^{\mathrm{aB}}$ & $\pm 1.69^{c C}$ & $\pm 1.11^{\mathrm{abB}}$ & $\pm 1.72^{\mathrm{aBC}}$ & $\pm 1.50^{\mathrm{bcB}}$ \\
\hline \multirow{2}{*}{ MM7 } & 7.92 & 19.32 & 17.57 & 12.37 & 12.59 & 14.28 & 9.82 \\
\hline & $\pm 0.88^{c C}$ & $\pm 2.94^{\mathrm{a} A \mathrm{~B}}$ & $\pm 1.70^{\mathrm{aB}}$ & $\pm 1.75^{\mathrm{bc}}$ & $\pm 1.83^{\mathrm{bCD}}$ & $\pm 1.60^{\mathrm{abc}}$ & $\pm 1.68^{\mathrm{cC}}$ \\
\hline \multirow{2}{*}{ MM2-3 } & 17.82 & 23.60 & 22.70 & 23.48 & 24.79 & 22.57 & 17.52 \\
\hline & $\pm 1.45^{\mathrm{bA}}$ & $\pm 2.27^{\mathrm{aA}}$ & $\pm 3.27^{\mathrm{aA}}$ & $\pm 3.21^{\mathrm{aA}}$ & $\pm 2.60^{\mathrm{aA}}$ & $\pm 3.24^{\mathrm{aA}}$ & $\pm 2.06^{\mathrm{bA}}$ \\
\hline
\end{tabular}




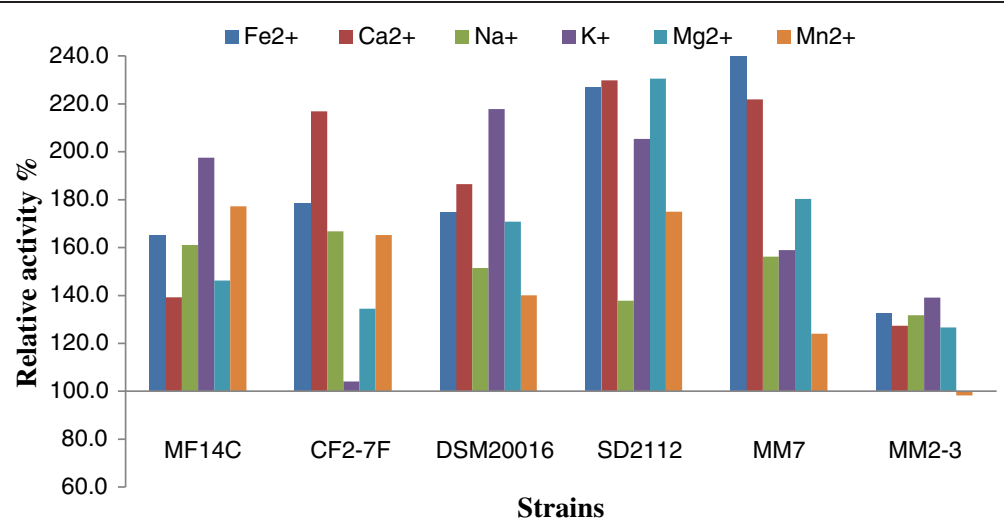

Figure 4 Relative activity (\%) of $\beta$-glucosidase produced by L. reuteri grown in SPM with added metal ions compared to the control group without metal ions. The relative activity was calculated as the enzymatic activity in SPM with added metal ions divided by the enzymatic activity in SPM without metal ions then multiplied by 100.

$143.9 \%$ (Figure 4). The addition of $\mathrm{Fe}^{2+}$ enhanced $\beta$ glucosidase activity produced by $L$. reuteri MM7 and $L$. reuteri SD2112 by $143.9 \%$ and $126.7 \%$ respectively. $\mathrm{Ca}^{2+}$ enhanced $\beta$-glucosidase activity produced by $L$. reuteri MM7 and $L$. reuteri SD2112 by $121.8 \%$ and $129.8 \%$ respectively. The addition of $\mathrm{K}^{+}$enhanced $\beta$-glucosidase produced by $L$. reuteri $\mathrm{CF} 2-7 \mathrm{~F}$ and $L$. reuteri SD2112 by $4.1 \%$ and $117.8 \%$ respectively. The effect of metal ions on $\beta$-glucosidase activity of $L$. reuteri MM2-3 was relatively low compared to other strains. Thus, the effect of metal ions on $\beta$-glucosidase activity produced by $L$. reuteri is strain dependent. Previous studies also showed that the effect of metal ions on $\beta$-glucosidase activity varied with the bacterial strain and type of metal ions (Pham et al. 2000). The effect of metal ions on $\beta$-glucosidase may be explained by that the bacterial sources of $\beta$-glucosidase have the highest activity and the most tolerance to inhibitors such as metal ions compare to other sources (Jeng et al. 2011). The growth of L. reuteri DSM20016 or MM2-3 in the presence of $\mathrm{K}^{+}$could be used to produce high quantity of $\beta$-glucosidase. Thus, our results suggest the addition of $\mathrm{Ca}^{2+}$ and $\mathrm{Fe}^{+2}$ to produce enhanced levels of $\beta$-glucosidase.

$\beta$-Glucosidase activity of $L$. reuteri was determined in the disrupted cells. However, $\beta$-glucosidase was also tested in the supernatant after removal of the cells but only trace of enzyme activity was detected (data not shown). Thus, $\beta$-glucosidase produced by the tested $L$. reuteri strains is mainly cell-associated enzyme. $\beta$ Glucosidase was also reported to be a cell-associated enzyme in L. acidophilus (Mahajan et al. 2010) and $L$. rhamnosus $\mathrm{R}$ (Pham et al. 2000). The absence of $\beta$ glucosidase in the supernatant may suggest that most

Table 4 Effect of metal ions on acid phosphatase activity (Ph U/mL) produced by L. reuteri

\begin{tabular}{|c|c|c|c|c|c|c|c|}
\hline \multirow[b]{2}{*}{ L. reuteri } & \multicolumn{7}{|c|}{ Acid phosphatase activity $(\mathrm{Ph} \mathrm{U} / \mathrm{mL})^{*}$} \\
\hline & Control & $\mathrm{Fe}^{2+}$ & $\mathrm{Ca}^{2+}$ & $\mathrm{Na}^{+}$ & $\mathrm{K}^{+}$ & $\mathrm{Mg}^{2+}$ & $\mathrm{Mn}^{2+}$ \\
\hline \multirow{2}{*}{ MF14-C } & 13.59 & 14.51 & 19.14 & 13.49 & 13.74 & 22.24 & 14.06 \\
\hline & $\pm 1.51^{\mathrm{bB}}$ & $\pm 1.24^{\mathrm{bB}}$ & $\pm 1.51^{\mathrm{aB}}$ & $\pm 0.98^{\mathrm{bB}}$ & $\pm 0.74^{\mathrm{bc}}$ & $\pm 2.49^{\mathrm{aB}}$ & $\pm 0.90^{\mathrm{bC}}$ \\
\hline \multirow{2}{*}{ CF2-7F } & 14.28 & 13.44 & 20.45 & 14.88 & 18.69 & 27.81 & 24.29 \\
\hline & $\pm 1.2^{\mathrm{CB}}$ & $\pm 1.11^{\mathrm{CB}}$ & $\pm 2.16^{\mathrm{abB}}$ & $\pm 1.57^{\mathrm{CB}}$ & $\pm 1.16^{\mathrm{bB}}$ & $\pm 2.43^{\mathrm{aAB}}$ & $\pm 2.54^{\mathrm{aA}}$ \\
\hline \multirow{2}{*}{ DSM20016 } & 18.69 & 15.61 & 21.41 & 20.00 & 20.96 & 29.33 & 18.91 \\
\hline & $\pm 1.15^{\mathrm{bcA}}$ & $\pm 2.40^{\mathrm{CB}}$ & $\pm 2.01^{\mathrm{bB}}$ & $\pm 1.27^{\mathrm{bA}}$ & $\pm 2.19^{\mathrm{bB}}$ & $\pm 2.36^{\mathrm{aA}}$ & $\pm 1.95^{\mathrm{bcB}}$ \\
\hline \multirow{2}{*}{ SD2112 } & 20.55 & 19.73 & 24.78 & 20.50 & 26.64 & 23.25 & 23.46 \\
\hline & $\pm 0.74^{\mathrm{bA}}$ & $\pm 0.36^{\mathrm{bA}}$ & $\pm 0.91^{\mathrm{aA}}$ & $\pm 0.95^{\mathrm{bA}}$ & $\pm 1.39^{\mathrm{aA}}$ & $\pm 2.38^{\mathrm{aB}}$ & $\pm 2.07^{\mathrm{aA}}$ \\
\hline \multirow{2}{*}{ MM7 } & 12.60 & 14.65 & 18.43 & 13.75 & 13.74 & 14.88 & 17.27 \\
\hline & $\pm 1.63^{\mathrm{cB}}$ & $\pm 0.98^{\mathrm{abB}}$ & $\pm 2.66^{\mathrm{aB}}$ & $\pm 2.37^{\mathrm{bcB}}$ & $\pm 1.20^{\mathrm{bcc}}$ & $\pm 1.31^{\mathrm{abc}}$ & $\pm 2.53^{\mathrm{aBC}}$ \\
\hline \multirow{2}{*}{ MM2-3 } & 8.73 & 9.52 & 14.65 & 11.91 & 10.12 & 14.24 & 12.71 \\
\hline & $\pm 1.11^{c C}$ & $\pm 1.14^{\mathrm{bcc}}$ & $\pm 1.21^{\mathrm{aC}}$ & $\pm 1.41^{\mathrm{abBC}}$ & $\pm 1.31^{\mathrm{bcD}}$ & $\pm 1.49^{\mathrm{aC}}$ & $\pm 1.37^{\mathrm{abCD}}$ \\
\hline
\end{tabular}


of extracted enzyme could be inactivated when separated from the cells.

\section{Induction of acid phosphatase by metal ions}

Acid phosphatase in control group ranged between $8.73 \pm$ 1.11 and $20.56 \pm 0.74 \mathrm{Ph} \mathrm{U} / \mathrm{mL}$ (Table 4). The addition of $\mathrm{Mg}^{2+}$ enhanced acid phosphatase activity of $L$. reuteri DSM20016 to reach the highest activity among tested strains, $29.33 \pm 2.36 \mathrm{Ph} \mathrm{U} / \mathrm{mL} . \mathrm{Mg}^{2+}$ caused significant $(p<0.05)$ increase in acid phosphatase activity in all tested strains. Acid phosphatase produced by $L$. reuteri SD2112 was significantly $(p<0.05)$ increased in the presence of $\mathrm{K}^{+}$or $\mathrm{Ca}^{2+}$ to reach $26.64 \pm 1.39$ and $24.78 \pm 0.91$ $\mathrm{Ph} \mathrm{U} / \mathrm{mL}$ respectively. The addition of $\mathrm{Mn}^{2+}$ increased acid phosphatase activity of $L$. reuteri CF2-7F by 10.1 units to reach $24.29 \pm 2.54 \mathrm{Ph} \mathrm{U} / \mathrm{mL}$. Figure 5 shows the relative effect of metal ions on acid phosphatase. Acid phosphatase produced by $L$. reuteri CF2-7F was increased by $94.7 \%$ and $70.1 \%$ in the presence of $\mathrm{Mg}^{2+}$ and $\mathrm{Mn}^{2+}$ respectively. The addition of $\mathrm{Ca}^{2+}$ led to enhance acid phosphatase activity in $L$. reuteri MM2-3 by $67.8 \% . \mathrm{Fe}^{2+}$ and $\mathrm{Na}^{+}$caused only slight effect (decrease or increase) on acid phosphatase. For example $\mathrm{Fe}^{2+}$ decreased acid phosphatase activity of $L$. reuteri DSM20016 by $16.5 \%$.

The relative activity data suggested that the addition of $\mathrm{Mg}^{2+}, \mathrm{Ca}^{2+}$, or $\mathrm{Mn}^{2+}$ may lead to high increase in acid phosphatase. $\mathrm{Mn}^{2+}$ was reported to stimulate phosphatase activity which was explained by the fact that many protein phosphatases contain $\mathrm{Mn}^{2+}$ (Pallen and Wang 1985). However, the effect of metal ions on acid phosphatase produced by $L$. reuteri was found to be a strain dependent. Previous studies also showed that the effect of metal ions on acid phosphatase activity varied with bacterial strain (Aqel 2012; Palacios et al. 2005).

\section{Induction of phytase by metal ions}

Phytase activity in control group ranged between $0.51 \pm$ 0.04 and $0.90 \pm 0.05 \mathrm{Ph} \mathrm{U} / \mathrm{mL}$ (Table 5). The growth of L. reuteri DSM20016 in the presence of $\mathrm{Ca}^{2+}$ led to the highest phytase activity, $1.16 \pm 0.20 \mathrm{Ph} \mathrm{U} / \mathrm{mL}$. Phytase activity of $L$. reuteri SD2112 reached $1.03 \pm 0.06 \mathrm{Ph} \mathrm{U} /$ $\mathrm{mL}$ in the presence of $\mathrm{Mn}^{2+}$. The addition of $\mathrm{Ca}^{2+}$ or $\mathrm{Mn}^{2+}$ to SPM enhanced phytase activity in all tested strains. On the other hand, phytase activity of $L$. reuteri DSM20016 was significantly $(p<0.05)$ decreased in the presence of $\mathrm{Na}^{+}$to reach $0.46 \pm 0.15 \mathrm{Ph} \mathrm{U} / \mathrm{mL}$. Phytase produced by $L$. reuteri DSM20016 was also reduced by $\mathrm{Fe}^{2+}, \mathrm{K}^{+}$, and $\mathrm{Mg}^{2+}$. Figure 6 shows the relative activity of $L$. reuteri in the presence of metal ions. Phytase produced by MM2-3 was increased by $74.5 \%$ in the presence of $\mathrm{Mn}^{2+}$. The addition $\mathrm{Mg}^{2+}$ enhanced phytase activity of MM2-3 by $51.0 \%$ and caused slight increase or decrease in the other strains. The addition of $\mathrm{K}^{+}$enhanced phytase activity of MF14-C and MM2-3 and decreased phytase activity of DSM20016 and SD2112. Thus, our results suggested the addition of $\mathrm{Mg}^{2+}, \mathrm{Mn}^{2+}$, and $\mathrm{Ca}^{2+}$ to the culture media of $L$. reuteri to enhance the production of phytase. In addition, the effect of metal ions on phytase activity of $L$. reuteri was found to be a strain dependent.

The effect of metal ions on phytase activity of Lacto bacillus was also investigated in previous studies. The addition of $\mathrm{Ca}^{2+}$ was previously reported to enhance phytase activity of Lactobacillus (Tang et al. 2010) and the addition of $\mathrm{Fe}^{2+}$ strongly inhibited phytase activity of $L$. sanfranciscensis (De Angelis et al. 2003). On the other hand, phytase activity of $L$. reuteri was found low compared to other tested enzymes. Lactobacillus strains had higher activity against $\rho$-nitrophenyl phosphate than phytate (Palacios et al. 2005). In addition, phytase does not

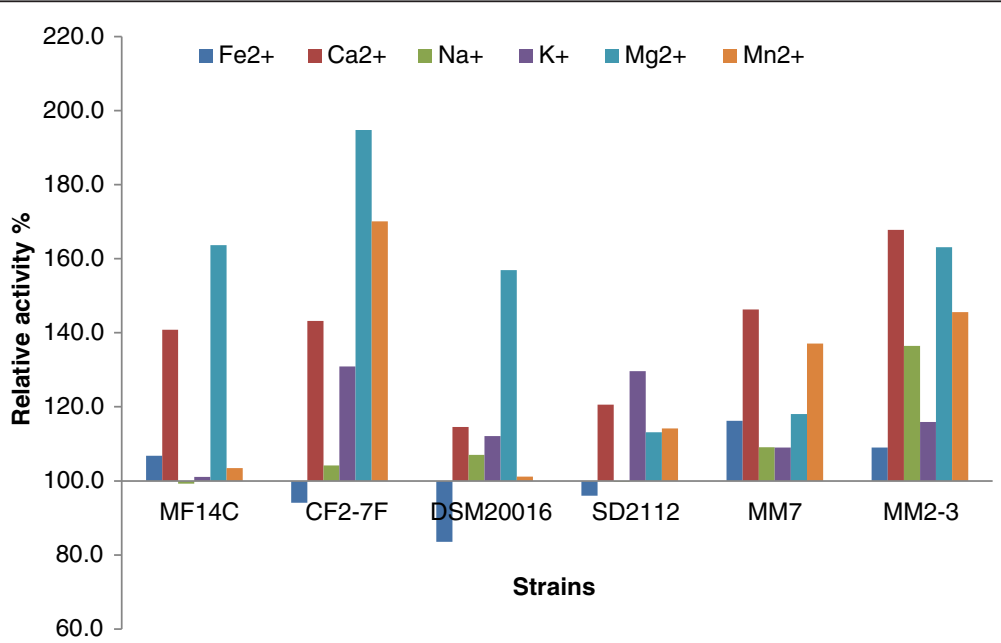

Figure 5 Relative activity (\%) of acid phosphatase produced by L. reuteri grown in SPM with added metal ions compared to the control group without metal ions. The relative activity was calculated as the enzymatic activity in SPM with added metal ion divided by the enzymatic activity in SPM without metal ions then multiplied by 100. 
Table 5 Effect of metal ions on phytase activity $(\mathrm{Ph} \mathrm{U} / \mathrm{mL})$ produced by $L$. reuteri

\begin{tabular}{|c|c|c|c|c|c|c|c|}
\hline \multirow[b]{2}{*}{ L. reuteri } & \multicolumn{7}{|c|}{ Phytase activity (Ph U/mL)* } \\
\hline & Control & $\mathrm{Fe}^{2+}$ & $\mathrm{Ca}^{2+}$ & $\mathrm{Na}^{+}$ & $\mathrm{K}^{+}$ & $\mathrm{Mg}^{2+}$ & $\mathrm{Mn}^{2+}$ \\
\hline \multirow{2}{*}{ MF14-C } & 0.72 & 0.63 & 0.76 & 0.64 & 0.93 & 0.81 & 0.87 \\
\hline & $\pm 0.08^{\mathrm{bcBC}}$ & $\pm 0.06^{\mathrm{CA}}$ & $\pm 0.11^{\mathrm{abBC}}$ & $\pm 0.05^{\mathrm{CAB}}$ & $\pm 0.08^{\mathrm{aA}}$ & $\pm 0.05^{\mathrm{abA}}$ & $\pm 0.05^{\mathrm{abB}}$ \\
\hline \multirow{2}{*}{ CF2-7F } & 0.67 & 0.62 & 0.78 & 0.55 & 0.69 & 0.81 & 0.95 \\
\hline & $\pm 0.05^{\mathrm{bcc}}$ & $\pm 0.07^{\mathrm{bcA}}$ & $\pm 0.08^{\mathrm{bB}}$ & $\pm 0.04^{\mathrm{cB}}$ & $\pm 0.05^{\mathrm{bBC}}$ & $\pm 0.06^{\mathrm{bA}}$ & $\pm 0.06^{\mathrm{aA}}$ \\
\hline \multirow{2}{*}{ DSM20016 } & 0.90 & 0.67 & 1.16 & 0.46 & 0.61 & 0.73 & 0.81 \\
\hline & $\pm 0.05^{\mathrm{abA}}$ & $\pm 0.04^{\mathrm{CA}}$ & $\pm 0.20^{\mathrm{aA}}$ & $\pm 0.15^{\mathrm{cBC}}$ & $\pm 0.23^{\mathrm{bcBC}}$ & $\pm 0.19^{\mathrm{bAB}}$ & $\pm 0.17^{\mathrm{abA}}$ \\
\hline \multirow{2}{*}{ SD2112 } & 0.81 & 0.64 & 0.99 & 0.68 & 0.63 & 0.66 & 1.03 \\
\hline & $\pm 0.06^{\mathrm{bAB}}$ & $\pm 0.05^{\mathrm{CA}}$ & $\pm 0.06^{\mathrm{aA}}$ & $\pm 0.03^{\mathrm{bcA}}$ & $\pm 0.04^{\mathrm{CBC}}$ & $\pm 0.08^{\mathrm{bcB}}$ & $\pm 0.06^{\mathrm{aA}}$ \\
\hline \multirow{2}{*}{ MM7 } & 0.68 & 0.61 & 0.78 & 0.59 & 0.76 & 0.82 & 0.91 \\
\hline & $\pm 0.04^{\mathrm{bcc}}$ & $\pm 0.06^{\mathrm{CA}}$ & $\pm 0.06^{\mathrm{abB}}$ & $\pm 0.09^{c B}$ & $\pm 0.06^{\mathrm{abB}}$ & $\pm 0.04^{\mathrm{aA}}$ & $\pm 0.14^{\mathrm{aAB}}$ \\
\hline \multirow{2}{*}{ MM2-3 } & 0.51 & 0.47 & 0.65 & 0.45 & 0.63 & 0.77 & 0.89 \\
\hline & $\pm 0.04^{\mathrm{CD}}$ & $\pm 0.04^{\mathrm{CB}}$ & $\pm 0.04^{\mathrm{bc}}$ & $\pm 0.03^{\mathrm{cC}}$ & $\pm 0.11^{\mathrm{bBC}}$ & $\pm 0.05^{\mathrm{bAB}}$ & $\pm 0.03^{\mathrm{aB}}$ \\
\hline
\end{tabular}

*Data points with different lower case letters in the same row are significantly $(p<0.05)$ different. Data points with different upper case letters in the same column are significantly $(p<0.05)$ different.

seem to be common in Lactobacillus strains and phytase activity of Lactobacillus is generally low compared to other bacterial genera (De Angelis et al. 2003; Palacios et al. 2005). However, phytase and acid phosphatase are particular subgroups of phosphatases, whereas phytase exhibits a preference for phytate. The specificity of both acid phosphatase and phytase can partially overlap since acid phosphatase also shows phytase activity (Simon and Igbasan 2002). Thus, both acid phosphatase and phytase can be useful in the degradation of phytate.

\section{Conclusion}

We studied the growth and enzymatic activity of $L$. reuteri in SPM. Our results demonstrate that the enzymatic activity of $L$. reuteri is strain dependent. $\alpha$-Glucosidase activity of L. reuteri MFI4-C and DSM20016 was enhanced by $\mathrm{Mg}^{2+}$ and $\mathrm{Mn}^{2+}$. The addition of $\mathrm{Ca}^{2+}, \mathrm{Fe}^{+2}$, or $\mathrm{K}^{+}$can enhance $\beta$-glucosidase activity of $L$. reuteri SD2112, DSM20016, and MM7. Acid phosphatase and phytase produced by MM2-3, CF2-7F, or MM7 could be increased by the addition of $\mathrm{Mg}^{2+}, \mathrm{Ca}^{2+}$, and $\mathrm{Mn}^{2+}$. Thus, to maximize the production of a target enzyme, it is required to select a combination of specific strain and specific metal ion. Nevertheless, $\mathrm{Mn}^{2+}$ and $\mathrm{Mg}^{2+}$ could be added to the culture media of $L$. reuteri to enhance the growth and enzymatic activity. Our results also revealed that more attention should be given to $L$. reuteri DSM20016 as high enzymatic activity is associated with this strain. Further studies need to done to investigate the optimum concentrations and possible combinations

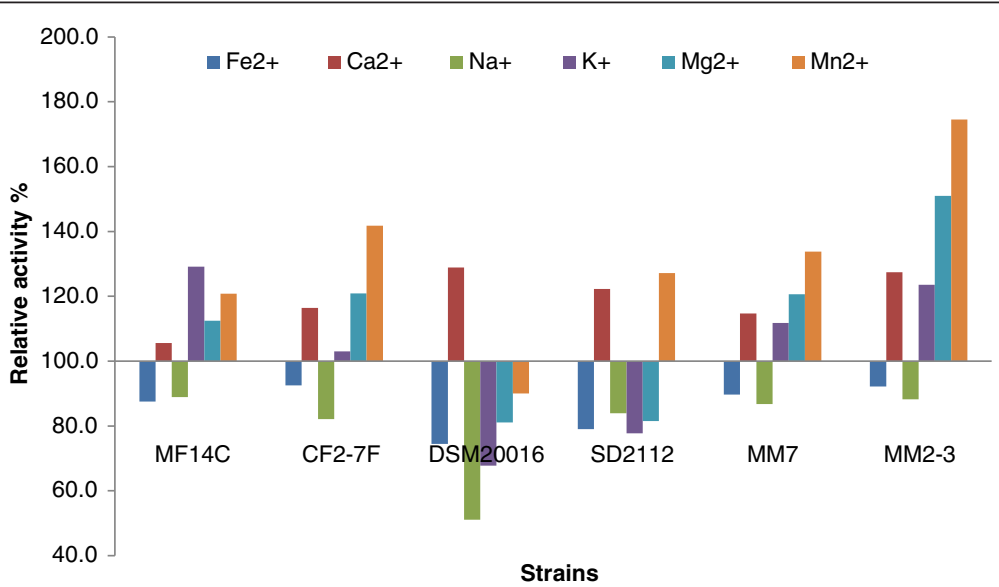

Figure 6 Relative activity (\%) of phytase produced by L. reuteri grown in SPM with added metal ions compared to the control group without metal ions. The relative activity was calculated as the enzymatic activity in SPM with added metal ion divided by the enzymatic activity in SPM without metal ions then multiplied by 100. 
of metal ions that could be used to maximize the enzymatic activity of $L$. reuteri.

\section{Competing interests}

Authors have declared that no competing interests exist.

\section{Authors' contributions}

SAH and SAI defined the research theme, experimental design, samplings, reviewed the literature, conducted the research experiments, interpret the results, and wrote the manuscript. AS and MW helped with the experimental design, data interpretation, and manuscript writing and editing. All authors read and approved the final manuscript.

\section{Acknowledgments}

This publication was made possible by grant number NC.X-267-5-12-170-1 from the National Institute of Food and Agriculture and its contents are solely the responsibility of the authors and do not necessarily response the official view of the National Institute of Food and Agriculture. The authors like to thank: Dr. K. Schimmel, for his support while conducting this work.

Received: 7 May 2013 Accepted: 11 September 2013

Published: 16 September 2013

\section{References}

Alazzeh AY, Ibrahim SA, Song D, Shahbazi A, AbuGhazaleh AA (2009) Carbohydrate and protein sources influence the induction of $a$-and $\beta$-galactosidases in Lactobacillus reuteri. Food Chem 117:654-659

Amouzou K, Prevost H, Divies C (1985) Effects of milk magnesium supplementation on lactic acid fermentation by Streptococcus lactis and Streptococcus thermophilus. Le Lait 65:21-34

Aqel H (2012) Effects of pH-Values, temperatures, sodium chloride, metal ions, sugars and Tweens on the acid phosphatase activity by thermophilic Bacillus strains. Eur J Sci Res 75:262-268

Barrangou R, Lahtinen SJ, Ibrahim F, Ouwehand AC (2011) Genus lactobacilli. In: Lahtinne S, Salminen S, Von Wright A, Ouwehand A (ed) Lactic acid bacteria: microbiological and functional aspects, 1st edition. CRC Press, London

Boyaval P (1989) Lactic acid bacteria and metal ions. Lait 69:87-113

Broihier K (2006) Sweet potato: tuber delivers top-notch nutrition. Environ Nutr 29:8-8

Bury D, Jelen P, Geciova J (2001) Effect of yeast extract supplementation on beta-galactosidase activity of Lactobacillus delbrueckii subsp. bulgaricus 11842 grown in whey. Czech J Food Sci 19:166-170

Casas IA, Dobrogosz WJ (2000) Validation of the probiotic concept: Lactobacillus reuteri confers broad-spectrum protection against disease in humans and animals. Microb Ecol Health D 12:247-285

De Angelis M, Gallo G, Corbo MR, McSweeney PL, Faccia M, Giovine M, Gobbetti M (2003) Phytase activity in sourdough lactic acid bacteria: purification and characterization of a phytase from Lactobacillus sanfranciscensis CB1. Int J Food Microbiol 87:259-270

Gyawali R, Ibrahim SA (2012) Impact of plant derivatives on the growth of foodborne pathogens and the functionality of probiotics. Appl Microbiol Biotechnol 95:29-45

Haros M, Bielecka M, Honke J, Sanz Y (2008) Phytate-degrading activity in lactic acid bacteria. Polish J Food Nutr Sci 58:33-40

Hayek SA (2013) Use of sweet potato to develop a medium for cultivation of lactic acid bacteria. Dissertation, North Carolina Agricultural and Technical State University

Hayek SA, Ibrahim SA (2013) Current limitations and challenges with lactic acid bacteria: a review. Food Nutr Sci. in press

Hayek SA, Shahbazi A, Awaisheh SS, Shah NP, Ibrahim SA (2013) Sweet potato as a basic component in developing a medium for the cultivation of lactobacilli. Biosci Biotechnol Biochem. in press

Hébert EM, Raya RR, Giori GS (2004) Nutritional requirements of Lactobacillus delbrueckii subsp. lactis in a chemically defined medium. Currunt Microbiol 49(5):341-345

Ibrahim SA, Alazzeh AY, Awaisheh SS, Song D, Shahbazi A, AbuGhazaleh AA (2010) Enhancement of $\alpha$-and $\beta$-galactosidase activity in Lactobacillus reuteri by different metal ions. Biol Trace Elem Res 136(1):106-116

lqbal TH, Lewis KO, Cooper BT (1994) Phytase activity in the human and rat small intestine. Gut 35(9):1233-1236

Jeng WY, Wang NC, Lin MH, Lin CT, Liaw YC, Chang WJ, Liu Cl, Liang PH, Wang AHJ (2011) Structural and functional analysis of three $\beta$-glucosidases from bacterium Clostridium cellulovorans, fungus Trichoderma reesei and termite Neotermes koshunensis. J Struct Biol 173:46-56
Kralj S, Stripling E, Sanders P, van Geel-Schutten GH, Dijkhuizen L (2005) Highly hydrolytic reuteransucrase from probiotic Lactobacillus reuteri strain ATCC 55730. Appl Environ Microbiol 71(7):3942-3950

Krasikov W, Karelov DV, Firsov LM (2001) a-Glucosidases. Biochem (Moscow) 66(3):267-281

Letort C, Juillard V (2001) Development of a minimal chemically defined medium for the exponential growth of Streptococcus thermophilus. J Appl Microbiol 91(6):1023-1029

Li KB, Chan KB (1983) Production and properties of $a$-glucosidase from Lactobacillus acidophilus. Appl Environ Microbiol 46(6):1380-1387

López-González AA, Grases F, Roca P, Mari B, Vicente-Herrero MT, Costa-Bauzá A (2008) Phytate (myo-inositol hexaphosphate) and risk factors for osteoporosis. J Med Food 11(4):747-752

Mahajan PM, Desai KM, Lele SS (2010) Production of cell membrane-bound $a$-and $\beta$-glucosidase by Lactobacillus acidophilus. Food Bioprocess Technol 5:706-718

Otieno DO, Ashton JF, Shah NP (2005) Stability of $\beta$-glucosidase activity produced by Bifidobacterium and Lactobacillus spp. in fermented soymilk during processing and storage. J Food Sci 70(4):M236-M241

Ozimek LK, Euverink GJW, Van Der Maarel MJEC, Dijkhuizen L (2005) Mutational analysis of the role of calcium ions in the Lactobacillus reuteri strain 121 fructosyltransferase (levansucrase and inulosucrase) enzymes. FEBS Let 579(5):1124-1128

Padmaja G (2009) Uses and nutritional data of sweetpotato. In: Loebenstein G, Thottappilly G (ed) The Sweetpotato. Springer, Belgium, Germany

Palacios MC, Haros M, Rosell CM, Sanz Y (2005) Characterization of an acid phosphatase from Lactobacillus pentosus: regulation and biochemical properties. J Appl Microbiol 98(1):229-237

Palacios MC, Haros M, Sanz Y, Rosell CM (2007) Selection of lactic acid bacteria with high phytate degrading activity for application in whole wheat breadmaking. LWT Food Sci Technol 41:82-92

Pallen CJ, Wang JH (1985) A multifunctional calmodulin-stimulated phosphatase. Arch Biochem Biophys 237(2):281-291

Pham P, Dupont I, Roy D, Lapointe G, Cerning J (2000) Production of exopolysaccharide by Lactobacillus rhamnosus $R$ and analysis of its enzymatic degradation during prolonged fermentation. Appl Environ Microbiol 66(6):2302-2310

Raghavendra P, Halami PM (2009) Screening, selection and characterization of phytic acid degrading lactic acid bacteria from chicken intestine. Int J Food Microbiol 133:129-134

Rodríguez H, Curiel JA, Landete JM, de las Rivas B, de Felipe FL, Gómez-Cordovés C, Mancheño JM, Muñoz R (2009) Food phenolics and lactic acid bacteria. Int J Food Microbiol 132(2-3):79-90

Sestelo ABF, Poza M, Villa TG (2004) $\beta$-Glucosidase activity in a Lactobacillus plantarum wine strain. World J Microbiol Biotechnol 20:633-637

Simon O, Igbasan F (2002) In vitro properties of phytases from various microbial origins. Int J Food Sci Technol 37(7):813-822

Song D, Ibrahim S, Hayek S (2012) Recent application of probiotics in food and agricultural science. In: Rigobelo EC (ed) Probiotics, 1st edition. InTech, Manhattan NY

Tang AL, Wilcox G, Walker KZ, Shah NP, Ashton JF, Stojanovska L (2010) Phytase activity from Lactobacillus spp. in calcium-fortified soymilk. J Food Sci 75(6):M373-M376

Tanner JT, Barnett SA (1986) Methods of analysis of infant formula: food and drug administration and infant formula council collaborative study, phase III. J Assoc Off Anal Chem 69:777-785

Tham S, Chang C, Huang H, Lee Y, Huang T, Chang C (2010) Biochemical characterization of an acid phosphatase from Thermus thermophilus. Biosci Biotechnol Biochem 74:727-735

Wegkamp A, Teusink B, De Vos WM, Smid EJ (2010) Development of a minimal growth medium for Lactobacillus plantarum. Lett Appl Microbiol 50(1):57-64

Zotta T, Ricciardi A, Parente E (2007) Enzymatic activities of lactic acid bacteria isolated from Cornetto di Matera sourdoughs. Int J Food Microbiol 115:165-172

Zotta T, Parente E, Ricciardi A (2009) Viability staining and detection of metabolic activity of sourdough lactic acid bacteria under stress conditions. World J Microbiol Biotechnol 25(6):1119-1124

\section{doi:10.1186/2193-1801-2-465}

Cite this article as: Hayek et al:: Enzymatic activity of Lactobacillus reuteri grown in a sweet potato based medium with the addition of metal ions. SpringerPlus 2013 2:465. 